\title{
Isolation and Number of Gonadal Primordial Germ Cells (Gonadal PGCs) on the Stages of Early Embryonic Development of KUB Chicken
}

\author{
S. Sopiyana ${ }^{\mathrm{a}, *}$, M. A. Setiadii ${ }^{\mathrm{b}}$, M. Fahrudin ${ }^{\mathrm{c}}$, \& I. Supriatna ${ }^{\mathrm{b}, *}$ \\ andonesian Research Institute for Animal Production \\ Jalan Veteran III, Desa Banjarwaru, Ciawi-Bogor 16002, Indonesia \\ 'Department of Veterinary Clinic, Reproduction, and Pathology, Faculty of Veterinary Medicine, \\ Bogor Agricultural University, \\ 'Department of Anatomy, Physiology, and Pharmacology, Faculty of Veterinary Medicine, \\ Bogor Agricultural University, \\ Jalan Agatis, Kampus IPB Darmaga, Bogor 16680, Indonesia \\ (Received 24-01-2017; Reviewed 08-03-2017; Accepted 22-03-2017)
}

\begin{abstract}
Primordial germ cells (PGCs) are cells that will differentiate themselves into spermatogonia in the testis or oogonia in the ovary. Primordial germ cells arise from epiblast and circulate through the bloodstream and finally entering gonadal anlage. The aim of this study was to determine the number of gonadal PGCs of KUB chicken at different development stages. Sixty KUB chicken fertile eggs were divided into four groups $\left(6,7,8\right.$, and 9 days incubation periods), and incubated at $38^{\circ} \mathrm{C}$ with a humidity of $60 \%$. Harvesting was synchronized to the embryonic development at 6-9 d. Gonads were collected using sharp tweezers, and were placed in Eppendorf tube $1.5 \mathrm{~mL}$ containing $500 \mu \mathrm{L}$ PBS [-]. Gonadal PGCs were purified using PBS [-]. The results showed that the average number of gonadal PGCs at 6, 7, 8, and $9 \mathrm{~d}$ were 113.7; 143.5; 92.9; and 85.7 cells per embryo, respectively. Number of gonadal PGCs per embryo of KUB chicken were significantly affected by stage of embryonic development $(\mathrm{P}<0.05)$, which reached a peak at day 7 of incubation, so that the isolation and collection of PGCs from the gonads were recommended at day 7 of incubation. This information is useful in production of germline chimera of other Indonesian local chickens.
\end{abstract}

Keywords: KUB chicken, embryo development, gonad, PGCs

\section{ABSTRAK}

Primordial germ cell (PGC) adalah sel yang akan berdiferensiasi menjadi spermatogonia dalam testis atau oogonia dalam ovarium. Primordial germ cell berasal dari epiblast di daerah germinal crescent dan beredar melalui aliran darah dalam waktu singkat sebelum memasuki bakal gonad. Setelah migrasi ke gonad, PGC disebut primordial germ cell gonad (PGC gonad). Penelitian ini bertujuan mengetahui jumlah PGC gonad ayam KUB pada tahap perkembangan embrio yang berbeda. Dalam penelitian ini digunakan 60 butir telur fertil ayam KUB yang dibagi menjadi empat kelompok perlakuan $\left(6,7,8\right.$, dan 9 hari periode inkubasi) yang diinkubasi pada suhu $38^{\circ} \mathrm{C}$ dengan kelembapan $60 \%$. Pemanenan disesuaikan dengan tahap perkembangan embrio pada 6-9 hari. Gonad diisolasi menggunakan pinset yang tajam, dan dikumpulkan pada tabung Eppendorf 1,5 mL yang berisi 500 $\mu \mathrm{L}$ larutan PBS [-]. PGC dimurnikan dengan menggunakan PBS [-]. Hasil penelitian menunjukkan bahwa rataan jumlah PGC gonad pada umur embrio 6, 7, 8, dan 9 hari pada ayam KUB berturut-turut adalah 113,7; 143,5; 92,9; dan 85,7 sel per embrio. Jumlah PGC gonad per embrio ayam KUB dipengaruhi oleh tahap perkembangan embrio $(\mathrm{P}<0,05)$, yang mencapai puncaknya pada hari ke-7 inkubasi sehingga isolasi dan koleksi PGC yang berasal dari gonad disarankan dipanen pada hari ke-7 inkubasi. Hasil penelitian berguna untuk produksi germline chimera untuk preservasi PGC ayam lokal Indonesia lainnya.

Kata kunci: ayam KUB, perkembangan embrio, gonad, PGC

${ }^{*}$ Corresponding author:

E-mail: soni sopiyana@yahoo.com; iman_sprtn@yahoo.com 


\section{INTRODUCTION}

Indonesia has around 43 breeds of local chickens (Sartika et al., 2016). Some of the local chicken populations are very limited in number and even many of them are in the status of endangered species. Some of them have potentially high benefit that have to be preserved in-situ or ex-situ. Kampung Unggul Badan Litbang Pertanian (KUB) chicken is one of the genetic resources of Indonesian Kampung chicken breeds, selected for improved egg production conducted at the Indonesian Research Institute for Animal Production. KUB chickens are able to produce eggs about $50 \%$ hen-day production, reaching peak productions of $65 \%-70 \%$ (Sartika et al., 2016). As a new breed, KUB chicken may be categorized as a new genetic resource.

Preservation can be divided into in-situ preservation and ex-situ preservation. The primary objective of preservation is to ensure the survival of threatened species and the maintenance of associated genetic diversity. In-situ or ex-situ preservation is a form of the living individual or population that needs high costs and risks associated with the disease. To solve the problem, it is necessary to develop a preservation strategy through the cryopreservation of genetic material, such as the storage of sperm, ova, and embryos in the frozen form (cryopreserved). However, the method of genetic resource preservation cannot be applied to poultry species primarily because of the technical difficulties on the cryopreservation of poultry eggs. The approach was developed to overcome the current limitations of in-situ and ex-situ preservations of genetic resources by collecting and transferring avian primordial germ cells (PGCs), collected from developing embryos.

Primordial germ cells are the progenitor cells for gametes that colonize the developing gonad and subsequently differentiate into spermatogonia in the testis or into oogonia in the ovary (Kohara et al., 2008; Qian et al., 2010; Glover \& McGrew, 2012). Chicken PGCs are located at the center of the pellucida area (Yamamoto et al., 2007). At the primitive streak stage, PGCs locates at the extra embryonic region that called germinal crescent region (Nakamura et al., 2007). As soon as the blood vessel is formed at stage 10 of Hamburger \& Hamilton (HH) (1951), The PGCs from the germinal crescent start to circulate temporarily through the embryonic bloodstream on day 2 of incubation. The cells leave the capillary system and migrate to the form of genital ridge, where they colonize the developing gonad (Minematsu et al., 2004; Glover \& McGrew, 2012). After migrating to the gonadal anlage, the PGCs are called gonadal germ cells (GGCs) (Nakajima et al., 2011). Gonadal germ cells or gonadal primordial germ cells (gonadal PGCs) in the gonad, ultimately differentiate into spermatogonia, which takes place in the testes or into oogonia, which takes place in the ovaries. Primordial germ cells are cells with pluripotent characteristic making the PGCs as a good model to study embryonic development in-vitro (Wang et al., 2010).

Primordial germ cells have a unique pathway of migration activity in birds (Song et al., 2010). The unique migration pathway of PGCs provides a possibility to isolate subsequent PGCs based on their locations. Primordial germ cells can be isolated from X-stage blastoderm, blood at 2.5-3-day-old embryos (stages 13-17 HH), or gonads at 5.5-6-day-old embryos (stages 26-28 HH) (Chojbacka-Puchta et al., 2012; Tajima, 2013). Numerous studies had reported the isolation and collection of PGCs from gonadal embryos (Nakamura et al., 2011; Nakajima et al., 2011; Nakajima et al., 2016). Moreover, germline chimeras had been produced in chicken by transferring PGCs or GGCs into the bloodstream at 2-day-old recipient embryos (Furuta et al., 2007, 2008) so that PGCs could be used as a genetic resource to produce germ line chimera (Furuta, 2012). Nakajima et al. (2012) reported that gonadal PGCs collected from 7-day-old chick embryos and incubated in PBS [-] can be used to produce germline chimeras. It has been reported that gonadal PGCs are used to generate interspecies germline chimeras by transferring pheasant gonadal PGCs into chicken embryos (Kang et al., 2008) and by transferring chicken gonadal PGCs into duck embryos (Liu et al., 2012).

One of the problems with the PGCs collection of embryonic blood at the age of 2.5 days is the low number of cells found in Indonesian local chicken (Kostaman et al., 2013). Therefore, to obtain more harvested PGCs, collection of PGCs from embryonic gonad can be used as an alternative method. There are several methods used to isolate avian gonadal PGCs, one is by using proteinases, such as trypsin solution (Park et al., 2008; Kohara et al., 2008) and the other is by using a phosphate-buffered saline without $\mathrm{Ca}^{2+}$ and $\mathrm{Mg}^{2+}$ solution (PBS [-]) (Nakajima et al., 2011). The present study was conducted to apply this method to isolate gonadal PGCs from KUB chicken embryos by using phosphatebuffered saline without $\mathrm{Ca}^{2+}$ and $\mathrm{Mg}^{2+}$ solution (PBS [-]) (Nakajima et al., 2011). The main objective of this study was to determine the number of gonadal PGCs of KUB chicken at different developmental stages of embryos. The results of the research are expected to be basic information for determining the appropriate stage for the isolation of gonadal PGCs.

\section{MATERIALS AND METHODS}

\section{Preparation of Fertilized Eggs}

Sixty fertilized eggs of KUB chickens, produced at the chicken research laboratory of Indonesian Research Institute for Animal Production, Bogor-Indonesia, were used in this research for gonads collection. Those eggs were divided into 4 treatment groups based on embryonic development on days $6,7,8$, and 9 of incubation to obtain embryos at stage 29-35 of $\mathrm{HH}$. The collected eggs were incubated at $38^{\circ} \mathrm{C}$ with humidity of $60 \%$ and rotated $90^{\circ}$ every $30 \mathrm{~min}$ in a portable incubator (P-008B Biotype; Furanki Showa, Saitama, Japan). The harvesting of embryos for each group was based on the age of embryonic development on days 6 to 9 . 


\section{Isolation and Collection of Gonadal PGCs}

Gonadal PGCs were isolated on days 5.5-6 or more than 6 days of embryonic gonads (stage 26-28 $\mathrm{HH}$ ) (Chojbacka-Puchta et al., 2012). In this study, gonadal PGCs were collected from the right and left gonads of KUB chicken embryos at the age of 6-9 d. Each embryo was separated from yolk and placed in a petri dish of 90 x $15 \mathrm{~mm}$ of LBS60001PT, BIOLAB. Thereafter, the embryos were rinsed with PBS [-]. The abdomen of the embryos and their contents were carefully dissected under microscope and the gonads were collected using sharp tweezers (Dumont No. 5L4 1/4 in., Inox alloy, Sigma Aldrich/F6521-1EA). The collected gonads were placed in an Eppendorf tube of $1.5 \mathrm{~mL}$ containing $500 \mu \mathrm{L}$ PBS [-]. The primordial germ cells were then collected using PBS [-] solution. The gonads were incubated using PBS [-] for one hour (Nakajima et al., 2011). The morphological characteristics and the total number of gonadal PGCs of KUB chicken were observed microscopically.

\section{Statistical Analysis}

The total number of gonadal PGCs of each embryonic development at the ages of $6,7,8$, and $9 \mathrm{~d}$ were analyzed statistically using Completely Randomized Design with 15 replications.

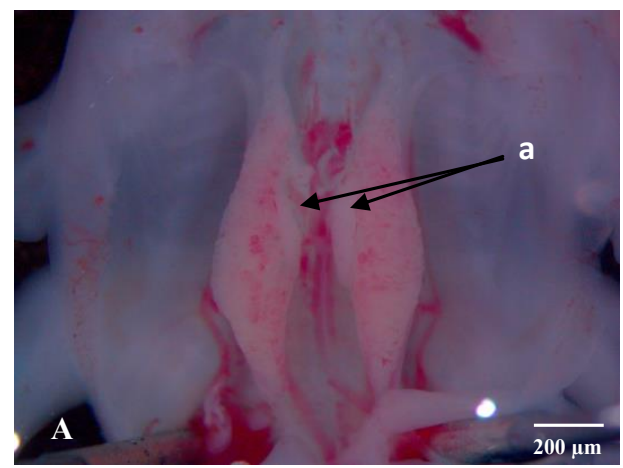

$$
Y_{i j}=\mu+\tau_{i}+\varepsilon_{i j}
$$

Note:

$\mathrm{Y}_{\mathrm{ij}}=$ any observation for which $\mathrm{X}_{1}=\mathrm{i}$

$\mu=$ general location parameter

$\tau_{\mathrm{i}}=$ effect of having treatment level $\mathrm{i}$

$\varepsilon_{\mathrm{ij}}=$ random error

Data were analyzed by ANOVA after their normal distribution was analyzed by Kolmogorof-Smirnov Z. The differences among groups were examined by Duncan's multiple-range test.

\section{RESULTS}

\section{Isolation and Identification of Gonadal PGCs from KUB Chicken}

Embryonic gonad is generally attached to the mesonephros (Figure 1). For the PGCs isolation, embryonic gonads should be separated from mesonephros attachment. Results under microscopic observations showed that gonadal PGCs that were released from the gonads reached a high number in $1 \mathrm{~h}$ after incubation of the gonads (Figure 2). This results show that gonadal PGCs can be isolated by incubating embryonic gonads of chicks in PBS [-] at $38^{\circ} \mathrm{C}$ for about $1 \mathrm{~h}$ (Nakajima \& Tajima, 2013).

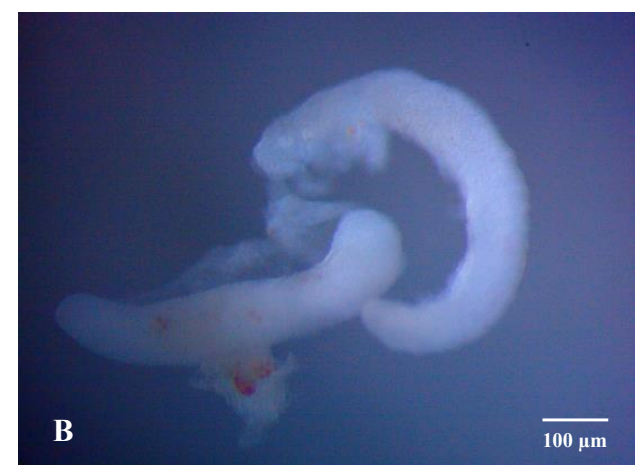

Figure 1. A) A pair of gonads (a) attached to the mesonephros chicken embryo. B) A pair of gonads that were removed from the mesonephros and ready to be isolated.
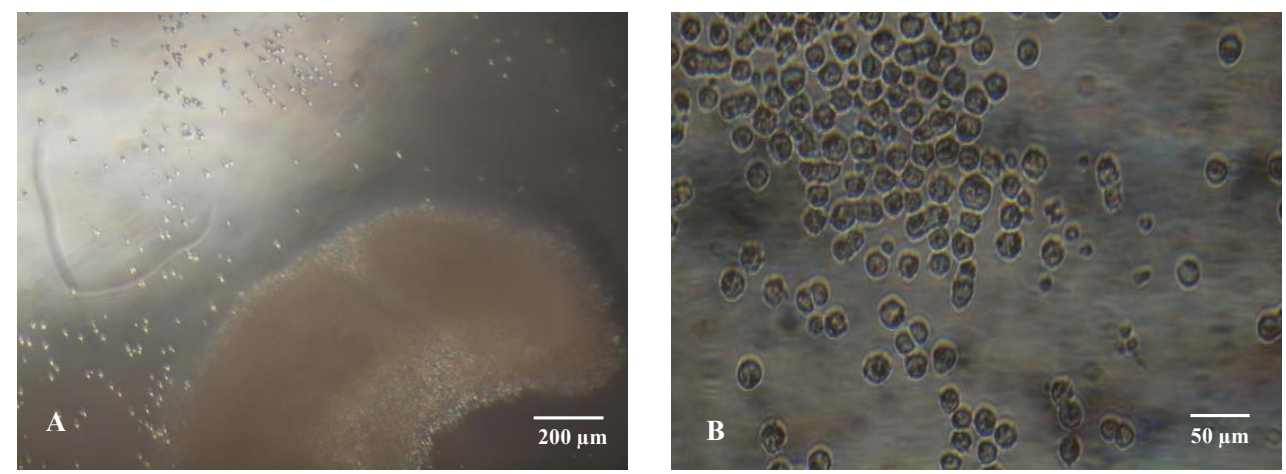

Figure 2. Gonadal PGCs cells from embryonic gonad of KUB chicken after 1 hour incubation in PBS [-] at $38^{\circ} \mathrm{C}$. A) PGCs released from gonad, B) harvested isolated PGCs. 
The results were in line with the results reported by Nakajima et al. $(2011 ; 2013)$ in White Leghorn (WL) and Rhode Island Red (RIR) chickens. The result also confirmed that PGCs isolation from gonad was easier and better with larger number of collected PGCs compared to the isolation of circulated PGCs.

Gonadal PGCs of KUB chicken had morphological characteristics: (1) large cell size, (2) bright lipid droplet distributed in the cytoplasm (3) spherical and large nucleus and located asymmetrically, (4) peripheral bright ring surrounding the cytoplasmic membrane. More details about KUB chicken PGCs characteristics are summarized in Table 1.

\section{Number of Gonadal PGCs}

The number of gonadal PGCs per embryo isolated from embryonic development on days 6, 7, 8, and 9 of incubation period (stage 29-35 of $\mathrm{HH}$ ) are presented in Table 2. Chojbacka-Puchta et al. (2012) reported that PGCs could be collected from embryonic gonad on days 5.5 to 6 . Further result of Minematsu et al. (2004) showed that PGCs began to migrate to the embryonic gonad starting on day 5 after incubation and subsequent PGCs began to play a part in the gonad between days 6 and 7 (at the onset of sexual differentiation) and sexual differentiation of the gonads were occurred after the arrival of germ cells. Meanwhile, germ cells multiplications are occurred at a later stage. Germ cells differentiation phase in female embryos took place between days 8 and 11 of incubation, whereas in male embryos, germ cells differentiation took place between days 13 and 15 of the incubation period.

In this study, gonads sampling of embryos was conducted on day 6 of incubation period, since most of PGCs had left the blood vessels and had begun to arrive in the gonadal anlage (Han, 2009). Collection of embryo gonads was terminated on day 9 of incubation because the PGCs remained stayed in the gonads. After that period, PGCs gradually differentiated into sex cells.

\section{DISCUSSION}

\section{Isolation and Identification of Gonadal PGCs from KUB Chicken}

The results of morphological characteristics of PGCs were consistent with the results reported by Kostaman et al. (2013) in Gaok chicken, Minematsu et al.

Table 1. Morphology characteristics of gonadal primordial germ cells (gonadal PGCs) in Kampung Unggul Badan Litbang Pertanian (KUB) chicken

\begin{tabular}{ll}
\hline Parameters & \multicolumn{1}{c}{ Gonadal PGCs } \\
\hline Diameter size $(\mu \mathrm{m})$ & $12.73-25.11$ \\
Morphology & Oval or round with irregular surface \\
Nucleus & Spherical, large, asymmetric, clear \\
Lipid droplets & Lipid droplets scattered in cytoplasm \\
Ring & Peripheral bright ring surrounding \\
& the cytoplasmic \\
\hline
\end{tabular}

(2004) in RIR chicken, Nakajima et al. (2016) in Oriental stork and Northern Bald ibis, and Sopiyana et al. (2016) in KUB chicken using the lysis buffer ACK method.

\section{Number of Gonadal PGCs}

Based on the results of previous studies, one of the problems in the PGCs collection of embryonic blood on day 2.5 was the low numbers of cells in local chickens that could be collected (Kostaman et al., 2013). On the contrary to those studies, our results revealed that the PGCs collection from days 6-9 yielded more PGCs compared to the collection method conducted on day 2.5. The highest number of gonadal PGCs $(\mathrm{P}<0.05)$ was obtained in the embryonic development at the stage of day 7 among the number of gonadal PGCs collected on days 6,8 , and 9 . This result showed that the number of gonadal PGCs was apparently influenced by the age of embryonic development.

Starting on day 6 of embryonic development, the number of gonadal PGCs significantly increased $(\mathrm{P}<0.05)$ and reached the peak number of gonadal PGCs on the embryonic development on day 7, which was probably that all PGCs might already reach the embryonic gonad as reported by Hong et al. (1995). Furthermore, this opinion was supported by Nakamura et al. (1988) that the PGCs had mostly settled down in the gonadal ridge on the day $7^{\text {th }}$ of the incubation period.

The number of PGCs slowly decreased $(\mathrm{P}<0.05)$ on days $8^{\text {th }}$ to $9^{\text {th }}$ incubation period. The reason of the decreased number of PGCs on the day 8th of incubation might be due to the start of PGCs to differentiate sexually to be a female embryo (Hong et al., 1995). Furthermore, PGCs began the meiotic division actively forming oogonia on days 8-9 of the incubation period (Van Krey, 1990).

Collection of PGCs from avian embryonic gonad, especially in Indonesian chickens, had not been done so far, so this preliminary study can be applied for genetic material preservation technology of embryonic gonad PGCs on Indonesian local chicken, especially for KUB chicken. The advantage of the collection of PGCs using PBS [-] has also been reported by Nakajima (2011) who incubated embryos for $30 \mathrm{~min}$ and obtained 402 cells per

Table 2. Number of harvested gonadal primordial germ cells (gonadal PGCs) per embryo of Kampung Unggul Badan Litbang Pertanian (KUB) chicken at incubation period of 6-9 days

\begin{tabular}{cc}
\hline $\begin{array}{c}\text { Incubation period } \\
\text { (days) }\end{array}$ & $\begin{array}{c}\text { Average number of gonadal PGCs } \\
\text { per embryo (cells) }\end{array}$ \\
\hline 6 & $113.7 \pm 7.7^{\mathrm{b}}$ \\
7 & $143.5 \pm 11.4^{\mathrm{a}}$ \\
8 & $92.9 \pm 10.9^{\mathrm{c}}$ \\
9 & $85.7 \pm 8.2^{\mathrm{d}}$ \\
SEM & 25.9 \\
\hline
\end{tabular}

Note: Means in the same column with different superscript differ significantly $(\mathrm{P}<0.05)$ 
embryo at embryonic age of $7 \mathrm{~d}$. Nakamura et al. (2011) harvested PGCs from gonads of WL chicken at the age of $7 \mathrm{~d}$ and obtained 237 cells per embryo.

This is the first report about gonadal PGCs in Indonesian local chicken, particularly in KUB chicken, although has lower number of PGCs compared to the number of PGCs resulted from exotic chicken as reported previously by Atsumi et al. (2008), Nakajima et al. (2011), and Nakamura et al. (2011). However results of this study were still comparable with the results reported by Nakajima et al. (2016) on Oriental stork and Northern Bald ibis with the averages number PGCs as much as 130 and 160 cells. The lower number of gonadal PGCs was influenced by the type of chicken (Zhao et al., 2003). The results of this present study indicated generally that KUB chicken as one type of Indonesian local chicken had lower number of PGCs compared to exotic chicken. This lower number of PGCs seems likely to be correlated with the lower productivity of local chicken, as was also stated by Zhao et al. (2003) that the number of chicken PGCs correlated with the number of eggs.

\section{CONCLUSION}

The highest number of gonadal PGCs of KUB chicken was obtained on day 7 of incubation period and it can be recommended that the best period time to isolate gonadal PGCs is on day 7.

\section{ACKNOWLEDGEMENT}

Authors thanked to Dr. Tatan Kostaman, S.Si., MP., Dr. Ir. Tike Sartika, M.Si., and Prof. (R) Dr. Ir. Sofjan Iskandar, M.Rur.Sc., who helped both material and nonmaterial until this research and article finished.

\section{REFERENCES}

Atsumi, Y., T. Tagami, H. Kagami, \& T. Ono. 2008. Restriction of germline proliferation by soft $\mathrm{X}$-ray of chicken embryos and its application to chimera production. J. Poult. Sci. 45:292-297. https://doi.org/10.2141/jpsa.45.292

Chojnacka-Puchta, L., K. Kasperczyk, G. Plucienniczak, D. Sawicka, \& Bednarczyk. 2012. Primordial germ cells (PGCs) as a tool for creating transgenic chickens. Polish. J. Vet. Sci. 15: 181-188. https://doi.org/10.2478/ v10181-011-0132-6

Furuta, H. 2012. Establishing germline chimeric chickens using primordial germ cells. J. Poult. Sci. 49:1-4. https://doi. org/10.2141/jpsa.011053

Furuta, H., S. Marumiya, I. Nakano, T. Yoshida, H. Mukouyama, \& M. Tanaka. 2007. Effect of transfer primordial germ cells (PGCs) into chick gonad. J. Poult. Sci. 44: 335-338. https:// doi.org/10.2141/jpsa.44.335

Furuta, H., T. Sawada, K. Nishikawa, I. Yamamoto, T. Yoshida, \& M. Tanaka. 2008. Transfer of blood containing primordial germ cells between chicken eggs development of embryonic reproductive tract. Cytotechnology 56:27-32. https://doi.org/10.1007/s10616-007-9096-x

Glover, J. D. \& M. J. McGrew. 2012. Primordial germ cells technologies for avian germplasm cryopreservation and investigating germ cell development. J. Poult. Sci. 49:155-162. https://doi.org/10.2141/jpsa.011161

Hamburger, V. \& H. L Hamilton. 1951. A series of normal stages in development of the chick embryo. J. Morphol. 88:49-92. https://doi.org/10.1002/jmor.1050880104

Han, J. Y. 2009. Germ cells and transgenesis in chickens. CIMID. 32:61-80. https://doi.org/10.1016/j.cimid.2007.11.010

Hong, Y. H., D. S. Seo, D. K. Jeong, K. D. Choi, \& J. Y. Han. 1995. Migration of the primordial germ cells and gonad formation in the early chicken embryo. AJAS. 5:557-562. https://doi.org/10.5713/ajas.1995.557

Kang, S. J., J. W. Choi, S. Y. Kim, K. J. Park, T. M. Kim, Y. M. Lee, H. Kim, J. M. Lim, \& J. Y. Han. 2008. Reproduction of wild birds via interspecies germ cell transplantation. Biol. Reprod. 79:931-937. https://doi.org/10.1095/ biolreprod.108.069989

Kohara, Y., Y. Kanai, \& A. Tajima. 2008. Cryopreservation of gonadal germ cells (GGCs) from the domestic chicken using vitrification. J. Poult. Sci. 5:57-61. https://doi.org/10.2141/ jpsa.45.57

Kostaman, T., T. L. Yusuf, M. Fahrudin, \& M. A. Setiadi. 2013. Isolation and number of circulated primordial germ cells (circulated-PGCs) on stages of embryonic development of Gaok chicken (In bahasa: Isolasi dan jumlah primordial germ cell sirkulasi (PGC-sirkulasi) pada stadium perkembangan embrio ayam Gaok). Indonesian Journal of Animal and Veterinary Sciences. 18:27-33.

Liu, C., K. A. Khazanehdari, V. Baskar, S. Saleem, J. Kinne, U. Wernery, \& I. K. Chang. 2012. Production of chicken progeny (Gallus gallus domesticus) from interspecies germline chimeric duck (Anas domesticus) by primordial germ cell transfer. Biol. Reprod. 86: Article 101, 1-8.

Minematsu T., A. Tajima, \& Y. Kanai. 2004. The migratory ability of gonadal germ cells in the domestic chicken. J. Poult. Sci. 41:178-185. https://doi.org/10.2141/jpsa.41.178

Nakajima Y., H. Fukuda, M. Onuma, K. Murata, M. Ueda, E. Sunaga, T. Shiraishi, \& A. Tajima. 2016. Migratory ability of gonadal germ cells (GGCs) isolated from Ciconia boyciana and Geronticus eremita embryos into the gonad of developing chicken embryos. J. Vet. Med. Sci. 78:1055-1058. https://doi.org/10.1292/jvms.15-0664

Nakajima, Y. \& A. Tajima. 2013. Development of a novel method for isolating gonadal germ cells from early chick embryos. J. Dev. Sustain. Agri. 8:75-78.

Nakajima, Y., M. Naito, \& A. Tajima. 2012. Production of germline chimeras by the transfer of gonadal germ cells (GGCs) recovered from 7-day-old chick embryos by using newly developed PBS [-] method. World Poult. Sci. J. 68, Supplement 1 .

Nakajima, Y., T. Minematsu, M. Naito, \& A. Tajima. 2011. A new method for isolation viable gonadal germ cells from 7-day-old chick embrios. J. Poult. Sci. 48:106-111. https:// doi.org/10.2141/jpsa.010094

Nakamura, M., T. Kuwana, Y. Miyayama, \& T. Fujimoto. 1988. Extragonadal distribution of primordial germ cells in the early chick embryo. Anat. Rec. 222:90-94. https://doi. org/10.1002/ar.1092220113

Nakamura, Y., F. Usui, D. Miyahara, T. Mori, H. Watanabe, T. Ono, K. Takeda, K. Nirasawa, H. Kagami H, \& T. Tagami. 2011. Viability and functionality of primordial germ cells after freeze-thaw in chicken. J. Poult. Sci. 48:57-63. https:// doi.org/10.2141/jpsa.010085

Nakamura, Y., Y. Yamamoto, F. Usui, T. Mushita, T. Ono, A. R. Setioko, K. Takeda, K. Nirasawa, H. Kagami, \& T. Tagami. 2007. Migration and proliferation of primordial germ cells in the early chicken embryo. J. Poult. Sci. 86:2182-2193. https://doi.org/10.1093/ps/86.10.2182

Park, T. S., M. A. Kim, J. M. Lim, \& J. Y. Han. 2008. Production of quail (Coturnix japonica) germline chimeras derived from in-vitro-cultured gonadal primordial germ cells. Mol. Rep. and Dev. 75:274-281. https://doi.org/10.1002/ mrd.20821

Qian, C., Z. Zhau, H. Han, C. Zhao, X. Jin, H. Zhao, Y. Zhang, 
W. Chen, N. Yang, \& Z. Li. 2010. Influence of microgravity on the concentration of circulating primordial germ cells in Silky chicken offspring. J. Poult. Sci. 47:65-70. https:// doi.org/10.2141/jpsa.009036

Sartika, T., S. Iskandar, \& B. Tiesnamurti. 2016. Sumberdaya Genetik Ayam Lokal Indonesia dan Prospek Pengembangannya. Indonesian Agency for Agricultural Research and Development Press, Jakarta, Indonesia.

Song, G., T. S. Park, T. M. Kim, \& J. Y. Han. 2010. Avian biotechnology: Insight from germ cells-mediated transgenic system. J. Poult. Sci. 47:197-207. https://doi.org/10.2141/ jpsa.009108

Sopiyana, S., I. Supriatna, M. A. Setiadi, \& M. Fahrudin. 2016. Determination of production capacity of circulated primordial germ cells (circulated-PGCs) of KUB chicken using lysis buffer ammonium chloride potassium (ACK). Indonesian Journal of Animal and Veterinary Sciences. 21:55-61. https://doi.org/10.14334/jitv.v21i1.1315
Tajima, A. 2013. Conservation of avian genetic resources. J. Poult. Sci. 50:1-8. https://doi.org/10.2141/jpsa.0120083

Van Krey, H. P. 1990. Reproductive biology in relation to breeding and genetics. In: Poultry Breeding and Genetics. Edited by R. D. Crawford. Elsevier Science Publisher, Amsterdam. Pp. 61-90.

Wang Y., L. Hou, C. Li, W. Guan, L. Chen, X. Li, W. Yue, \& Y. H. Ma. 2010. Isolation, culture, and biological characteristics of primordial germ cells from Beijing Fatty chicken. J. Reprod. Dev. 56:303-308. https://doi.org/10.1262/ jrd.09-126N

Yamamoto, Y., T. Ono, \& H. Kagami. 2007. Dynamic analysis of the developmental fate of cells in the center of the area pellucida of the blastoderm in chicken. J. Poult. Sci. 44:85-91. https://doi.org/10.2141/jpsa.44.85

Zhao, D. F., H. Yamashita, M. Matsuzaki, T. Takano, S. Abe, M. Naito, \& T. Kuwana. 2003. Genetic factors affect the number of circulating primordial germ cells in early chick embryos. J. Poult. Sci. 40:101-113. https://doi.org/10.2141/ jpsa.40.101 